\title{
Public Purpose As A Justification For Expropriation Of Rural Land Rights In Ethiopia
}

\author{
Brightman Gebremichael
}

\begin{abstract}
Expropriation of private land rights involves two contradictory interests. On one side, there is a public need for land; on the other side landholders need the provision of tenure security and protection of their private property rights. Thus, it needs to keep a balance between them. To create the intended balance, legislation has to authorize the government to expropriate land rights for clear and limited public purpose under the supervision of an independent body. In this article the writer will argue that the rural land laws of Ethiopia have defined the public purpose for expropriation of rural land rights in different manner depending on the nature of the landholders. For peasants and pastoralists the public purpose requirement is defined vaguely and broadly leaving its component to be determined by public authority. However, for investors the concept is limited to the projects implemented by the government. Moreover, the writer argues that the protection of private property rights and provision of land tenure security of holders is further undermined due to the legislation failure to authorize the affected people from taking an appeal to an independent body objecting the fact that the project to which the private rural landholding is expropriated does not satisfy the public purpose requirement.
\end{abstract}

Key words: land expropriation, public purpose, balancing interests, rural land laws, Ethiopia

\section{Introduction}

In any modern nation the realization of sustainable development requires governments to make available public facilities and infrastructure that ensure safety and security, health and welfare, social and economic enhancement, and protection and restoration of the natural environment. The acquisition of appropriate land is the early and first step to do these things. Nevertheless, the required land may not be in the hands of governments and also it may not be on sale at the time it is required. Then, in order to obtain land when and where it is needed, governments have the power of expropriation of land - the right of the nation or state, or of those to whom the power has been lawfully delegated, to condemn private property for public use, and to appropriate the ownership and possession of such property without the owner's or occupant's consent on paying the owner a due compensation to be ascertained according to law. ${ }^{1}$

\footnotetext{
${ }^{1}$ Francis, C. and et al, Eminent Domain, Corpus Juris Secundum, 29 A CJS EMINENT DOMAIN NO.2 as cited in W/Gebriel, Daniel, Compensation During Expropriation, in Muradu Abdo (ed), 2009, Land Law and Policy in Ethiopia since 1991: Continuities and Changes, Ethiopian Business Law Series Vol. III, AAU printing press, Addis Ababa, p194
} 
Land expropriation, which is also termed as compulsory acquisition, eminent domain, compulsory purchase, land acquisition or resumption, ${ }^{2}$ is one of the policy dialogue areas that are filled with tension. On one hand, it may ultimately bring benefits to society by enhancing social and economic development and the protection of the natural environment. On the other hand, to people whose land is acquired it causes displacement of families from their homes, farmers from their fields, and businesses from their neighbourhoods. These diverging out comes of land expropriation requires finding the balance between the public need for land, and the provision of land tenure security and the protection of private property rights of the holder. ${ }^{3}$

One of the basic principles to create the intended balance is limiting the use of this power to public purpose - the justifications offered for taking private land rights without attaining the owner's/occupant's consent. Accordingly, governments should expropriate private land rights only for clear public purposes that do not allow them to use this power extensively. ${ }^{4}$ Moreover, while legislation determine what constitutes public purpose it has to be clear enough so as to eliminate of the risk of losing the land rights to discretionary bureaucratic behaviour. ${ }^{5}$ Besides, people whose land is acquired on the ground of public purpose has to be given with the right to appeal to an independent body - court of law if they think that the purpose of the project to which the land is acquired does not serve any of the public purposes. ${ }^{6}$ In contrast, unclear stipulation and excessively wide interpretation of public purpose without check and balance by an independent body may create incentives for corruption by private investors who may try to influence processes to their own advantage and it seriously undermines land tenure security and private property rights of individuals. Thus, that is why the prevailing legal opinion claims that the land expropriation to be done to specific and well-defined public purposes and that the affected peoples should be given with the possibility to appeal to the judiciary to prevent abuse of state powers by the bureaucracy. ${ }^{7}$ Whereas, when legislation designs this process poorly, in collaboration with other factors, it results in reduction of land tenure security of landholders. ${ }^{8}$

Nowadays, as a developing country Ethiopia has faced with rapid growing urbanization, modernization of infrastructures and agricultural investments. Most towns and cities in the country have been expanding in their size and incorporating the pervious rural areas. Moreover, since 1991 the country has opened its doors for foreign and national investment on the basis of free market economy and encourages private investors to participate in the establishment of large-scale commercial farms and agro-industries. As a result, a large portion of land is required for private and public investment, for the expansion of the existing and establishment of new urban centers, and for construction of roads and other types of infrastructure and public utilities in all areas of the country.

One of the means by which the government of Ethiopia can make such land available for the above purpose is expropriating private landholdings on the basis of public purpose. Nevertheless, while employing 'public purpose'

\footnotetext{
${ }^{2}$ FAO, 2008, Compulsory acquisition of land and compensation, Land Tenure Studies 10, Rome, Italy, p.1. this writer may employ these terms interchangeably.

${ }^{3}$ Ibid

${ }^{4}$ Deininger, Klaus, Land Policies for Growth and Poverty Reduction: A world Bank Policy Research report, the World Bank and Oxford University Press, World Bank Washington DC,2003, p.173

${ }^{5}$ Ibid at p.170 and see also above notes 2 at p. 6

${ }^{6}$ above notes 4 and above notes 2 at p. 6 and pp.45-48

${ }^{7}$ Deininger, Klaus and Jin, Songqing Securing Property Rights in Transition: Lessons from Implementation of China's Rural Land Contracting Law, Policy Research Working Paper 4447, The World Bank Development Research Group Sustainable Rural and Urban Development Team December 2007, p.5

${ }^{8}$ See above notes 2 at p.6
} 
as a justification for expropriating private landholdings it should be in the manner of balancing the two competing interests stated above. Then, this article considers the way the justification for land expropriation - public purpose has been treated under the Ethiopian rural land legal framework to keep the balance between the interests involved during expropriation and its similarity for any landholder.

The first section highlights the general understanding of public purpose which is followed by the section that will address the power and manner it is determined. Section three presents the means revolved around public purpose that can serve to maintain the balance between the public need for land on one hand and provision of tenure security and protection of private land rights on the other hand. The fourth section is devoted to analyse how public purpose as a justification offered for taking of private rural land rights is treated under Ethiopian rural land laws. Finally, the conclusion, inter alia, pin points the areas that need legislative revision with respect to the rules regulating the public purpose so that the required balance is maintained.

\section{GENERAL UNDERSTANDING OF THE CONCEPT OF PUBLIC PURPOSE}

The concept of Public purpose that identifies the purpose for which the power of land expropriation is exercised or that provides the justifications offered for taking private land rights against the wish of the holder of the property is also identified in different terminologies in different countries legislation. To express the same idea different states constitutions and laws employ the terms like public use, public good, public interest and public benefit. ${ }^{9}$ Though these terms are coined to express the same principle and tend to be used interchangeably, their meanings are different and sometimes even controversial. To see an instance, compared to the others the notion of 'public interest' is wider and creates more space for unaccountable decision making; and for instance, expropriation of land to lease for private investors may well be in public interest, when it generates an important source of income for the state. $^{10}$

Beside terminological differences the meaning of public purpose has become elusive and tricky and has been tried to be defined by different literatures, of course, differently. Then, it is not as such important to address executively all those definitions. Rather, for the consumption of this section let us see two of them. To begin, the dictionary definition of Public purpose is "an action by or at the direction of the government for the benefit of the community as whole". 11 This definition implies that public purpose is a justification for the act of the government including eminent domain which has been exercised to benefit the public in general and not individual. ${ }^{12}$ However,

\footnotetext{
9 above notes 2 at p.10 and see also W/Gebriel, Daniel, Compensation During Expropriation, in Muradu Abdo (ed), 2009, Land Law and Policy in Ethiopia since 1991: Continuities and Changes, Ethiopian Business Law Series Vol. III, AAU printing press, Addis Ababa, p. 195. In Ethiopia as well different terminologies are adopted in legislation for the same concept. For instance under the its constitution and the federal rural land law the phrase 'public propose' has been employed for it. Whereas, the Amhara and Benishagul Gummuz States' rural land laws and Southern Nations, Nationalities and Peoples rural land law have adopted 'public service' and 'public use' respectively for the same concept.

10 De Wit, Paul, and et al, LAND POLICY DEVELOPMENT IN AN AFRICAN CONTEXT, LESSONS LEARNED FROM SELECTED EXPERIENCES, Land Tenure Working Paper 14, FOOD AND AGRICULTURE ORGANIZATION OF THE UNITED NATIONS, October 2009, p.72

${ }^{11}$ Black's Law Dictionary, $7^{\text {th }}$ ed., s.v. "public purpose"

${ }^{12}$ Raja Muhammed Muzaffar, Compulsory Acquisition of Land, (1967), p.40
} 
this definition is defective in a sense that it does not specify the nature of the benefits the society derive from the proposed project for which the compulsory acquisition is conducted. This situation leads someone to interpret the nature of benefits into two ways. One plausible understanding may be that it is actually be done by, and hence available for actual use by, the general public, as is true, for example, of a public park or highway. ${ }^{13}$ The other way of understanding, on the other, is that it may be the inclusion of both the actual use and the indirect benefit like improvement of the locality's tax base or job base without the direct use of the expropriated land. ${ }^{14}$

On the other hand, George S.Gulic more clearly has defined public purpose as:

"A public benefit or pubic advantage and may embrace anything tending to enlarge the product of capacity or resource of the community and to promote the general welfare and prosperity.",15

This definition seems somewhat clear enough in determining the nature of the benefits to society to justify the expropriation. The definition has adopted both the actual and indirect benefits to the community while considering anything that tends to promote the general welfare of the society to constitute the public purpose. Therefore, the meaning of public purpose is ultimately based on the widely accepted understanding that the general interest of the community or a section thereof, overrides the particular interest of the individual.

Nevertheless, the aforementioned two definition of public purpose are still not sufficed to specify exactly what constitutes public purpose. Then, it is a necessity to appreciate its components in this juncture. In the early times expropriation of private property for the traditional function of states such as education, highways and defence was equivalent to public purpose. ${ }^{16}$ Nevertheless, nowadays, the concept tends to encompass various complex socioeconomic activities; and that is why the ambit of public purpose is highly influenced by the development of economic, social and political aspects of particular society. ${ }^{17}$ Again countries' legislation still varies on the components of public purpose. The reason for this is the inherent subjective nature of the concept itself and its openness to the influence of prevailing view of "fairness" and the party with the greater bargaining power. ${ }^{18}$ Meanwhile, based on its broad survey of both developed and developing countries Food and Agricultural Organization (FAO) has identified the following as accepted public purposes for land expropriation: ${ }^{19}$

- Transportation uses including roads, canals, highways, railways, bridges, wharves and airports;

- $\quad$ Public buildings including schools, libraries, hospitals, factories, religious institutions and public housing;

- Public utilities for water, sewage, electricity, gas, communication, irrigation and drainage, dams and reservoirs;

- $\quad$ Public parks, playgrounds, gardens, sports facilities and cemeteries;

- $\quad$ Defense purposes.

${ }^{13}$ Dana, David A., Exclusionary Eminent Domain, Supreme Court Economic Review, Vol. 17, No. 1 (February 2009), pp. 7-62, p.14

${ }^{14}$ Ibid at p. 15

${ }^{15}$ George S. Gulic and Robert T. Kimbrough, American Jurisprudence, Vol. 26 (1966),p.665

${ }^{16}$ Dunning, Harrison C., Law and Economic Development in Africa: The Law of Eminent Domain, Columbia Law Review, Vol. 68, No. 7 (Nov., 1968), pp. 1286-1315, p.1298

${ }^{17}$ V.G Ramachandran, The Law of Land Acquisition and Compensation, (1963), p.321

${ }^{18}$ Langford, M. and Halim, U., Path of least resistance: a human rights perspective on expropriation, in FAO, 2008, Land Reform, Land Settlement and Cooperatives, land reform 2008/1, p.39

${ }^{19}$ above notes 2 at p.11 
Beside these purposes, the FAO has also made its determinations on the controversial situation that happens where private land is acquired by government and then transferred to private investors/developers and large businesses on the justification that the change in ownership/use will benefit the public as it happen in some countries. Here, still it may be argued that the development benefits the wider public indirectly by creating economic growth and jobs, and by increasing the tax base which in turn allows the government to improve its delivery of public services. ${ }^{20}$ However, in such cases, the FAO advices governments to undertake a public scrutiny on proposals to use compulsory acquisition of land to ensure that the balance between the public need for land and the protection of private property rights is properly considered, and that the compensation reflects the profit potential of the land to be acquired. ${ }^{21}$ (Emphasis added)

\section{MANNER AND POWER OF DETERMINING THE COMPONENTS PUBLIC PURPOSES}

Traditionally, the functions of government are divided into three broad classes: legislative, executive (or administrative) and judicial (or adjudicatory). Yet 'it is not always easy, or indeed possible, to determine under which head a particular task of government falls,' although the organs which mainly perform these functions are distinguishable. $^{22}$ Moreover, countries experiences are not similar in assigning task of government among these organs. The task assigned to the legislative organ in one country may be authorized to the judiciary or executive organ in other countries.

One area of such variations occurs in the authority to specify what constitutes the public purpose for compulsory acquisition of land. In some countries, a constitution tend to include a specific list of the purposes for which land may be compulsorily acquired without assigning this power to neither of the government organs. A prominent instance in this regard is the Constitution of Ghana and Chile. Ghana's and Chile's constitution includes provisions detailing exactly what kinds of projects allow the government to use its power of compulsory acquisition $^{23}$. Again, in other countries, this power is given to the legislative organ. For instance, in Poland the Expropriation Law of 1991 which was enacted by the legislative organ has listed the public purposes. ${ }^{24}$ Furthermore, in others this task is designated to the judiciary organ. Here, first the expropriating organ compulsorily acquires the private land rights without the consent of the holder. Nevertheless, the land holder may aggrieves with this decision and takes an action to the judiciary on the basis of objecting the purpose of the project by stating that the project

${ }^{20}$ Ibid, at p. 12

${ }^{21}$ Ibid

${ }^{22}$ E. C. S. Wade and G. G. Phillips, Constitutional and Administrative Law, London, 42. As cited in Ebeku, K. S. A., The Separation of Powers in Local Government in Nigeria, Journal of African Law, Vol. 36, No. 1 (Spring, 1992), pp. 43-51, p.44

${ }^{23}$ above notes 2 at p.7 For instance in Ghana Article 20 of the 1992 Constitution provides that:

(1) No property of any description, or interest in or right over any property shall be compulsorily taken possession of or acquired by the State unless the following conditions are satisfied:

(a) the taking of possession or acquisition is necessary in the interest of defence, public safety, public order, public morality, public health, town and country planning or the development or utilization of property in such a manner as to promote the public benefit; and

Nevertheless, this is also not exhaustive listing rather it seems to leave the inclusion of others through constitutional interpretation by an organ empowered to interpret the constitution.

${ }^{24}$ above notes 2 at p. 11 
does not serve any of the public purposes. Thus, it is the judiciary that has a final saying on determining the components of the public purpose for expropriation of land. USA is a good example for this approach. ${ }^{25}$ The Fifth amendment of the constitution of the United States of America mandates that: "No person...shall be deprived of...property, without due process of law; nor shall private property be taken for public use without just compensation. Moreover, its other legislation has not defined it constituting elements. Rather, it is seems to be left for the interpretation of the courts. This can be inferred from the changing of the scope of public purpose through time in the country. Initially the approach taken by the country was a narrow one which literally required that the public derive gain from the expropriated property. ${ }^{26}$ However, without promulgation of any law the US Supreme Court's interpretation has widened its scope implying the possibility of taking of private property by the state to give to another private individual, which incidentally results in positive benefits for the public through economic development, meet the "public use" requirement. ${ }^{27}$

Finally, in some other countries, stipulation of the constituting elements of public purpose totally left for the executive organ. Currently prevailing legislation of Ethiopia reveals the upholding of this approach. In fact, the legislative organ has put some restriction on the executive organ's power of determining the components of public purpose but it has not subjected the decision of the later to the judicial review. ${ }^{28}$

Concerning the manner of listing of the components of public purpose, on the other side, it is possible to identify three different ways. The first way is exclusive listing whereby the legislation of the concerned state lists all possible purposes for which the government can compulsorily acquire private land rights. This approach reduces ambiguity by providing a comprehensive, non-negotiable list beyond which the government may not compulsorily acquire land. ${ }^{29}$ Nevertheless, the problem here is that it may be too rigid to provide for the full range of public needs; and the government may one day need to acquire land for a public purpose that was not considered when the law was enacted. ${ }^{30}$ This is because the expropriation to be legitimate the amendment of the legislation is necessary to add the newly emerged public purposes. The problem is more exaggerated when the exclusive listing of the components of public purpose is made in the constitution of a given country's constitution; since the amendment of it needs the satisfaction stringent prerequisites.

The second approach is inclusive listing that contains some list of permissible purposes, along with an openended clause to allow the necessary flexibility. This approach identifies specific purposes for which land may be acquired and then adds a word or phrase that imply the government to expropriate land rights for similar purposes. This means, it provides the flexibility to expand the eligible purposes when required and at the same time, limiting the scope for expansion only to purposes similar in nature with the list of purposes provided as instance. ${ }^{31}$

\footnotetext{
${ }^{25}$ Ibid at p.7

${ }^{26}$ G., Alexander The Global Debate Over Constitutional Law (2006) The University of Chicago Press: Chicago, p.65

${ }_{27}$ Kelo v City of New London, 545 US 469, 478-80 (2005); dissenting) (arguing for a reading of the "public use" requirement as allowing the taking of property only if "the government owns, or the public has a legal right to use, the property, as opposed to taking it for any public purpose or necessity whatsoever"

${ }^{28}$ Federal Democratic Republic of Ethiopia, Expropriation of Landholding for Public Purposes and Payment of Compensation Proclamation No.455/2005, Fed. Neg. Gaz. No.43, year 11, (hereinafter cited as FDRE Land Expropriation Proc. No.455/2005), Art.2(5)

${ }^{29}$ above notes 2, p.11

${ }^{30}$ Ibid

${ }^{31}$ Ibid
} 
The final approach is that the legislation neither exhaustively nor in open-ended manner lists purposes for which a government can compulsorily acquire land rights. Instead, it leaves the determination of the public purpose to the appropriate executive body only ${ }^{32}$ or to the judicial interpretations. This approach provides the organs legislatively unchecked discretionary power.

Generally, besides these distinctions an exercise in compulsory acquisition is more likely to be regarded as legitimate if land is taken for a purpose clearly identified in legislation. ${ }^{33}$ Further, in order to reduce the scope for arbitrary and discretionary action by individual bureaucrats, legislations should be clear enough in circumscription of the state's right to expropriate land in noticeably identifiable public interest. ${ }^{34}$ Furthermore, to keep the equilibrium between the public need for land and the protection of private property rights the standards discussed in the subsequent section must be observed in specifying the public purpose for expropriation of land rights.

\section{BALANCING COMPETING INTERESTS INVOLVED IN EXPROPRIATION THROUGH PUBLIC PURPOSE REQUIREMENT}

The process of balancing conflicting interests is commonplace in many areas of the law, in the law of expropriation it is of primary importance. The critical review of different literatures reveals that the proceedings of land expropriation involve apparently conflicting interests. On one hand, there is an interest of the public represented by the government for the land. On the other hand, the private land holder has an interest for protection of private property rights and provision of land tenure security. Thus, it needs establishment of a balance between them.

In fact, there are various means for realizing this. Inter alia, public purpose requirement is the one. To establish the intended equilibrium the justifications for the expropriation - public purpose must satisfy the following standards. First, the government should expropriate individual land rights only for clear public purposes. ${ }^{35}$ In other words, an exercise in compulsory acquisition is more likely to be regarded as legitimate if land is taken for a purpose clearly identified in legislation. ${ }^{36}$ Further, in order to reduce the scope for arbitrary and discretionary action by individual bureaucrats, legislations should be clear enough in circumscription of the state's right to expropriate land in noticeably identifiable public interest. ${ }^{37}$ Perhaps, it can be clearly identified when the legislation list it in exhaustive or illustrative manner as it has seen in the above section. However, the difficulty occurs when the legislation leave the components of public purpose to be determined by the executive organ or by judicial interpretation. In this case, the individual landholders' legitimate expectation or certainty for what projects they loss their land rights is undermined.

Second, besides being clear, the components of public purpose should be narrow enough to keep the balance. As per the discussion made above the component of public purpose may range from direct or actual use of the expropriated land right by the society at large only to expropriating the land to transfer to the other individual

\footnotetext{
${ }^{32}$ FDRE Land Expropriation Proc. No.455/2005, Art.2(5)

33 above notes 2, p.11

${ }^{34}$ Above notes 4, p. 170

35 ibid

${ }^{36}$ Above notes 2, p.11

37 above notes 4 , p. 170
} 
investor that can benefit the society indirectly by creating job opportunity or serving as tax base. Meanwhile, the extensive use of state power to expropriate land rights seriously undermines tenure security of individual land rights. ${ }^{38}$ Nevertheless, there is no agreement among legal scholars on how narrowly to define the 'public purpose' requirement. ${ }^{39}$ In meantime, they unanimously recognize the dangers posed by an excessively wide interpretation in terms of creating incentives for corruption by private investors trying to influence processes to their own advantage, are well recognized in the literature. ${ }^{40}$

To curtail this problem, in the opinion of this writer for expropriation of private land rights on the grounds other than those listed by FAO seen above as components of public purpose; it is good to conduct public hearing in the process. ${ }^{41}$ The rationale for this is that since the expropriation is done for economic betterment of the public, we have to give an opportunity to it to decide in its own. In turn this entails the public to supervise the possibility of the grant of governments" "carte blanche for compulsory transfer of private property from ordinary citizens to politically-powerful" investors or real estate entrepreneurs. ${ }^{42}$

The final standard to realize the balanced approach of land expropriation through the public purpose requirement is granting the private land right holder with the right to appeal to independent body against the decision of expropriation. The World Bank has revealed that the involvement by the courts in the expropriation proceeding as one mechanism to protect private land right holders from abuse. ${ }^{43}$ Moreover, FAO has also implied that to keep the balance individual land right holders should be given the chance to contest the expropriation decision to a body that is independent of the acquiring agency; and legislation should provide opportunities for owners and occupants to appeal against the compulsory acquisition of their land. It is because Procedures to appeal protect the rights of affected people. ${ }^{44}$

Further, while legislation allows the appeal in this regard, it also specifically establishes the situation or ground thereto. One of such ground is appeal against the purpose of the project. ${ }^{45}$ Here, the affected people challenge that the project does not serve any of the public purposes for which compulsorily acquisition is allowed or their specific parcels are not needed for the project or that the project would be best located elsewhere. ${ }^{46}$ The affected people can prove this challenge when the constituting elements of public purpose is exhaustively listed since the purpose

\footnotetext{
${ }^{38}$ Above notes 4, p.173

${ }^{39}$ Harrington, M. P. 2002. "The original understanding of the so-called takings clause." Hastings Law Journal 53 (1): $345-85$.

${ }^{40}$ Kelly, D. B. 2006. "The Public Use Requirement in Eminent Domain Law: A Rationale Based on Secret Purchases and Private Influence." Cornell Law Review 92 (1): 1-66.

${ }^{41}$ De Wit, Paul, and et al, LAND POLICY DEVELOPMENT IN AN AFRICAN CONTEXT, LESSONS LEARNED FROM SELECTED EXPERIENCES, Land Tenure Working Paper 14, FOOD AND AGRICULTURE ORGANIZATION OF THE UNITED NATIONS, October 2009, p.72

${ }^{42}$ Lehavi, Amnon and Licht, Amir N. Eminent Domain, Inc., Columbia Law Review, Vol. 107, No. 7 (Nov., 2007), pp. 1704-1748, p. 1705

${ }^{43}$ Above notes 4, p.173

${ }_{45}^{4}$ Above notes 2, p.16 and 45

45 The other grounds are appeal against the procedures used to implement the expropriation and against the compensation value. While compulsorily acquiring land the government may fail to follow the legislatively established procedures; like improper notice, improper processing of compensation claim, delay in payment or payment to wrong person, unreasonable haste in pursuing acquisition and so on. At the same time, appeal against the compensation value occurs when the affected peoples perceive that the compensation offered for them for their land right is inadequate; and they claim for more money or other form of compensation.

${ }^{46}$ Above notes 2, p.46
} 
identified by the acquiring agency has to be on the list; or when it is listed in open-ended manner as the identified purposes provide a measure of restraint as the purpose of the project should be evaluated against them and a radical departure from the list may allow the review body to declare that the purpose of the project is not permissible by law. ${ }^{47}$ However, in absence of such listing in the legislation it is so difficult for affected people to argue that the expropriation is not essential and not for public purpose.

Despite the paramount role judicial review plays in maintaining the balance, it again needs a necessary care to be taken. This is because "a heavy volume of expensive and time-consuming state litigation continues, posing the serious problem of holdup suits by the affected peoples using dilatory litigation as a bargaining technique." ${ }^{48}$ This in return undermines the quick implementation of the intended project and the realization of sustainable development. In fact, the problem can be mitigated by limiting the procedure to appeal to certain situation wherein the expropriation is undertaken for projects other than FAO's listing as seen above and to those ground that has not explicitly listed in legislation. To express otherwise, affected people should be given opportunity to appeal against the purpose of the project only for expropriation conducted to transfer the land right to third parties and those grounds which are not included in the legislation listing.

To recap the legislation of countries are expected to incorporate these standards to assure the balanced approach. Otherwise, the non-regulation of the public purpose requirement as per above standards would result in the abridgement of private property rights and undermining the land tenure security thereto. Thus, here below the writer has evaluated the legislation of Ethiopia in this respect.

\section{PUBLIC PURPOSE REQUIRMENT UNDER ETHIOPIAN RURAL LAND LEGAL FRAMEWORK}

\subsection{FDRE constitution}

The Constitution of Federal Democratic Republic of Ethiopia (hereinafter the FDRE Constitution) under article 40 has provided the general rules on the manner of acquisition, nature and restriction of rural land rights. In fact, the constitution has made a differential treatment on these points based on the identity of the rural land holder. After provided Ethiopian peoples and the state joint ownership of land, ${ }^{49}$ it has guaranteed peasants and pastoralists with a free access to rural land; ${ }^{50}$ whereas, investors are allowed to rural land use right through a payment arrangement. ${ }^{51}$

Moreover, the constitution has also empowered the government to expropriate property rights in general for public purpose upon the payment of compensation. ${ }^{52}$ However, it has not defined the constituting elements of public purpose. It states that: ${ }^{53}$

47 Ibid

48 ___ State Constitutional Limitations on the Power of Eminent Domain, Harvard Law Review, Vol. 77, No. 4 (Feb., 1964), pp. 717-729, p.718

${ }^{49}$ Constitution of Federal Democratic Republic of Ethiopia, Proclamation No.1/1995, Fed. Neg. Gaz. $1^{\text {st }}$ year No.1, (hereinafter cited as FDRE Constitution), Art.40(3)

${ }^{50}$ FDRE Constitution, Art40(4) and (5)

${ }^{51}$ FDRE Constitution, Art.40(6)

${ }^{52}$ FDRE Constitution, Art.40(8) 
Without prejudice to the right to private property, the government may expropriate private property for public purposes subject to payment in advance of compensation commensurate to the value of the property.

Nevertheless, the cumulative reading of this provision with article 40(2) of the constitution may seem to imply that the government's power to expropriate the land rights of peasants and pastoralists is not sanctioned by the constitution. This argument is deducted because for one thing as it has seen above the constitution has authorized the government to compulsorily acquire private property for public purpose. For the other thing, the working definition provided for 'private property' in the constitution excludes the rural land rights of peasants and pastoralists. The constitution has defined 'private property' as; ${ }^{54}$

any tangible or intangible product which has value and is produced by the labour, creativity, enterprise or capital of an individual citizen, associations which enjoy juridical personality under the law, or in appropriate circumstances, by communities specifically empowered by law to own property in common.

Therefore, since the constitution has granted peasants and pastoralists with a right to obtain rural land without payment it does not fell under the ambit of 'private property' in accordance to the above definition. This is because even if the right has value but it is not the product of labour, creativity, enterprise or capital the peasants or pastoralists - one element in the definition of 'private property'. On the other side, since the investors acquire rural land use right upon payment, this land rights can satisfy the 'private property' definition of the constitution. So, expropriation of investors rural land rights is expressly promulgated in the constitution unlike that of peasants and pastoralists.

This situation may lead someone to argue on the constitutionality of the government authority to expropriate the rural land rights of peasants and pastoralists. However, from the practice of almost all modern nations in the world; the nature of protection of peasants' and pastoralists' land rights; the right to sustainable development of citizens; and socio-economic objectives specified in the FDRE constitution itself, it is still possible to argue that the government has the sovereign power to expropriate Ethiopian peasants' and pastoralists' rural land rights for public purpose. Concerning countries practice compulsory acquisition of land rights exists everywhere in the world. Even in countries that have the most individualistic system property, recognised private land tenure, and given a strong protection for property rights, the land rights individuals enjoy never been left unrestricted; but in its place it is limited by the government authority to expropriate such land rights when needed for the public interest at large. ${ }^{55}$ Thus, there is no unique ground to prohibit expropriation of peasants' and pastoralists' land rights in Ethiopia if it is needed for the greater societal interest.

On the top of this, the nature of protection that has been granted to Ethiopian peasants' and pastoralists' concerning their land rights in the Constitution is immunity against eviction and displacement respectively. That is, the constitution protects peasants and pastoralists from being deprived of their land rights arbitrarily without payment of compensation thereto. This baseline protection from forced eviction and displacement is needed and made just in order to ensure that unjust expropriations are less likely to occur. ${ }^{56} \mathrm{Then}$, in granting immunity against eviction and displacement, the FDRE Constitution is not prohibiting the government from compulsorily acquiring

\footnotetext{
${ }^{53}$ FDRE Constitution, Art.40(8)

${ }^{54}$ FDRE Constitution, Art.40(2)

55 above notes 4, p. 28

${ }^{56}$ Above notes 18, p.41
} 
peasants' and pastoralists' land rights for public purpose upon payment of compensation in accordance with expropriation legislation. Instead, it is requiring the government to compulsorily acquire their land rights in a way of paying compensation that enables peasants and pastoralists to perceive that they are not evicted and displaced.

This argument again may be supplemented by the national policy objectives enshrined in the constitution itself. More specifically, the economic and social objectives demand the government to endeavour to protect and promote the health, welfare and living standards of the working population of the country through ensuring all Ethiopians (including rural residents) access to public health and education, clean water, housing, food and social security. ${ }^{57}$ The realization of these developmental activities may require the government to access rural land for plantation of infrastructures. Therefore, it may be argued that the legislator of the constitution has presupposed the existence of government's power to acquire rural land without the consent of the holder for such public purpose. This is again inferred from the stipulation of the right to sustainable development under FDRE Constitution. ${ }^{58}$ It is because in order to realize this right of citizens the government is required to provide public facilities and infrastructures that may ensure safety and security, health and welfare, social and economic enhancement, and protection and restoration of the natural environment. ${ }^{59}$ The first step in the process of providing these facilities and infrastructures is the acquisition of appropriate land for their construction. The state land holdings may not be sufficient or convenient to the purpose at hand and purchase of land through land market from private land holders is not allowed as the FDRE constitution prohibited transfer of land rights through sale. ${ }^{60}$ Then, in order to obtain land when and where it is needed to be used for specific purposes to realize the right to sustainable development of citizens, the only option the government has left with is the power of compulsory acquisition of land.

Moreover, it is possible to justify the power of the government to expropriate rural land rights in Ethiopia by employing the canon of construction of laws - a fortiori. The FDRE Constitution as mentioned above has expressly authorized the government to compulsorily acquire 'private property' - product with value and produced by labor, creativity or capital of individuals and on which they have established complete bundle of rights, for public purpose upon advance payment of compensation commensurate to the value of the property. ${ }^{61}$ Then, for an even more reason the government has a power to compulsorily acquire rural land on which peasants and pastoralists have acquired for free by the operation of law and on which they have partial property rights property' where it deemed necessary for public purpose.

Consequently, for the aforementioned justifications the writer of this article believes that the government of Ethiopia is constitutionally authorized to compulsorily acquire the peasants' and pastoralists' land rights too for public purpose. However, the constitution seems to leave the definition and constituting element of public purpose for expropriation of land rights to the federal legislative body. This fact is inferred from the division of power made in the constitution. Particularly, when the constitution empowers the federal government to enact laws for the utilization and conservation of land and the state governments to administer in accordance to the federal laws in effect it is authorizing the former to determine components of public purpose. Moreover, the constitution has

\footnotetext{
${ }^{57}$ FDRE Constitution, Art.89(8) and Art.90

${ }^{58}$ FDRE Constitution, Art.43(1) It states that 'The peoples of Ethiopia... have the right to improved living standards and to sustainable development'

${ }^{59}$ Above notes 2, p. 1

${ }^{60}$ FDRE Constitution, Art.40(3)

${ }^{61}$ FDRE Constitution, Art.40(8)
} 
expressly recognised the right to access to justice and nationals' right to participate in national development and, in particular, to be consulted with respect to policies and projects affecting their community. Thus, below the writer has critical scrutinized the definition and components of public purpose stipulated under the subsidiary laws; and how they have employed the standards discussed in section three to keep a balance between public need for land and protection of property rights and provision of land tenure security for rural landholders.

\section{2. rural land laws of Ethiopia}

In Ethiopia the rural land tenure is regulated by both the federal and States' rural land laws. Here, the writer will try to analyse the public purpose requirement for expropriation rural land rights under the federal and some States rural land laws. The federal rural land law particularly Expropriation of landholdings for Public Purposes and Payment of Compensation Proclamation has defined 'public purpose' as: ${ }^{62} 63$

"the use of land defined as such by the decision of the appropriate body in conformity with urban structure plan or development plan in order to ensure the interest of the people to acquire direct or indirect benefits from the use of the land and to consolidate sustainable socio-economic development."

This definition has interpreted the concept of 'public purpose' in a very broad manner which opens the way for public authorities to consider any activity as serving the public purpose. Moreover, it has employed neither the exclusive nor inclusive listing of public purpose approach that limit the discretion of public authorities in the determination of the purpose to which land is compulsorily acquired. Rather, it came up with its own unique approach wherein the public purpose that is better for development to be determined by other appropriate body or relegated officials. However, the federal legislation fails to specify the appropriate body to which this task is assigned, though it seems the government body entrusted with the power of expropriation, i.e. woreda administration (the lowest administrative unit above Kebelle) or the higher regional or federal government body. Further, the legislation has specified two basic standards that may serve to identify the types of activities which lie on public purpose. Frist, the potential activity that will be carried on the compulsorily acquired land must be in conformity with the urban structure or development plan. Second, beside the conformity standard, the intended activity to which a peasant land holding is expropriated must ensure direct or indirect benefits of the society. However, these unclear guidance on what determines a valid "public purpose" for eminent domain implies that

\footnotetext{
${ }^{62}$ FDRE Expropriation Proc. No.455/2005, Art.2(5)

${ }^{63}$ Under Amhara and Benishangul Gummuz regions (among the federating states of the country) rural land laws; on the other hand, the concept of 'public purpose' has been defined seemingly in narrower sense compared to the federal legislation. In the same fashion both regions' laws have defined it as follows employing the terminology of 'public service':

"service given to the public directly or indirectly, such as government office, school, health service, market service, road, religious institutions, military camps, and the likes, and includes activities assumed important to the development of people by the Regional Government and to be implemented on the rural land."

Here, the two regions' legislations have defined the concept of 'public service' in an illustrative manner providing some lists of it. However, again in this definition the power of determining the other 'public services' has left to the respective regions' regulatory body based on "direct or indirect benefit to the society" standard without involving the public hearing in the process. Thus, "indirect benefit of society" standard employed in both laws would enable the governments of the respective regions to compulsorily acquire rural land of peasants to transfer to investors
} 
expropriation is often seen as arbitrary and inconsistent across the country; and there is substantial scope for officials to define "public interest" purposes for land expropriation. ${ }^{64}$ Thus, because the law does not specifically spell out such 'public purposes', it is possible to argue that the government has virtually unrestricted power to compulsorily acquire rural land.

When the federal legislation says the direct benefits to the society as standard for determination of public purpose, it is to imply that land is expropriated to those activities listed above as commonly accepted public purposes based on the FAO's survey of developed and developing countries. Whereas, the indirect benefits of the society standard has aimed at indicating the following two cases as public purpose for land expropriation. First, when peasants' and pastoralists' landholding is expropriated to lease to investors that indirectly benefit the society at large by creating economic growth and jobs, and by increasing the tax base which in turn allows the government to improve its delivery of public services. ${ }^{65}$ Secondly, indirect benefits of society emanate in situation where peasants' and pastoralists' holding is expropriated in urban expansion to make land available for urban growth to lease to urban dwellers for residential purpose by creating other income source to government to improve its delivery of public utilities. ${ }^{66}$

As W/Gebriel has noted, the incorporation of public purpose in its wider sense in the federal legislation is justified on the country's eagerness for development as developing country and its high dependence on whatever investment that can be made in its land by public entities, private investors, associations or other organs of the federal and regional governments. ${ }^{67}$ As result, the magnitude and pace of pro-poor expropriation may be outstripped by pro-big business expropriation. This the current vision of development in Ethiopia is favouring 'big' over 'small'. Particularly, expropriating peasants land rights to transfer to an investor who wish to engage in large scale farming should not be considered as 'public purpose'. It is because as the World Bank have conceded rather than large farmers small-scale farmers are economically more efficient. ${ }^{68}$

In fact, the above definition and way of determining "public purpose" for the purpose of rural land expropriation is not applicable to investors. This is because the federal law has come up with other way of defining and determining the public purpose requirement to expropriate investors' rural landholdings. That is investors' rural landholdings that are acquired through lease arrangement on the basis of payment would be expropriated if and only if their holdings are required for development works to be undertaken by the government itself. ${ }^{69}$ To express otherwise, unlike peasants and pastoralists in order to expropriate investors' rural landholdings before the expiry of the lease period a development activity to be carried out by other investors, cooperative societies or other organs is

${ }^{64}$ World Bank, Options For Strengthening Land Administration, Federal Democratic Republic Of Ethiopia, World Bank Document, Report No: 61631-ET, p.3

${ }_{65}^{65}$ Above notes 2, p.12

${ }^{66}$ Above notes 64

${ }^{67}$ See W/Gebriel, Daniel, Compensation During Expropriation, in Muradu Abdo (ed), 2009, Land Law and Policy in Ethiopia since 1991: Continuities and Changes, Ethiopian Business Law Series Vol. III, AAU printing press, Addis Ababa, p.196 and FDRE Land Expropriation Proc. No.455/2005, Art.3(1)

${ }_{60}^{68}$ Above notes 18, p39

${ }^{69}$ FDRE Constitution, Art. 40 (6) and all rural land laws of the federal and State governments indicate that investors can acquire rural land use right through lease from the government. 
not considered as "public purpose" to justify the expropriation. This is inferred while the federal legislation states that: ${ }^{70}$

"1/ A woreda or an urban administration shall, upon payment in advance of compensation in accordance with this Proclamation, have the power to expropriate rural or urban landholdings for public purpose where it believes that it should be used for a better development project to be carried out by public entities, private investors, cooperative societies or other organs, or where' such expropriation has been decided by the appropriate higher regional or federal government organ for the same purpose.

2/ Notwithstanding the provisions of Sub-Article (I) of this Article (referring to the above paragraph), no land lease holding may be expropriated unless the lessee has failed to honor the obligations he assumed under the Lease Proclamation and Regulations or the land is required for development works to be undertaken by government."

In this juncture, one may question the rationality of this discriminatory treatment of the legislation between peasants and pastoralists on one hand and investors on the other hand. The rational of the government for expropriating rural land rights of peasants and pastoralists to transfer to investors is just economic justification. To be precise, the government thinks the land may be efficiently utilized and become base of tax and employment opportunity, will allow for much needed foreign currency to enter into the economy and will contribute to long-term food security through the transfer of technology to small-scale farmers if it is given to investors than peasants and pastoralists. ${ }^{71}$ Then the writer does not think the existence of any reason and logic not to use the same justification for compulsory acquisition of rural land rights of investors. it is because in same fashion the new investor to whom the rural land is needed may utilize it more productive way; create more job opportunity and tax base; and may cause the entrance of more foreign currency and better technology than the previous investor. As result, in the opinion of the writer this discriminatory provision of the legislation has not been as such supported with any reasoning.

On the top of this, the legislator while providing expropriating rural land to transfer to investors it contradicts with other determination made in the legislation. This is especially true with regard to the stipulations made in the rural land laws prioritizing peasants, pastoralists and semi-pastoralists over others particularly private investors in accessing rural land. ${ }^{72}$ Here, the legislature has made logical and rational decision in giving a priority right to peasants and pastoralists in accessing rural land considering the purpose to which land is claimed - the peasants and pastoralists to sustain their livelihood whereas private investors for investment profit. However, this priority right of peasants and pastoralists becomes meaningless if the government is authorized to expropriate tomorrow the peasants' and pastoralists' landholding given today in order to lease to private investors on the ground of public purpose. Perhaps, it may be argued that the existence of priority right of peasants and pastoralists enable them to claim compensation even if the land is expropriated to give to private investors. Nevertheless, there are still problems in the valuation and amount of compensation to be paid for loss of land rights. ${ }^{73}$

${ }^{70}$ FDRE Land Expropriation Proc. No.455/2005, Art. 3 (1) and (2)

71 The Oakland Institute, Understanding Land Investment Deals in Africa, Country Report: Ethiopia, 2011, p.1

${ }^{72}$ Federal Democratic Republic of Ethiopia, Rural Land Administration and Land Use Proclamation No. 456/2005, Fed. Neg. Gaz. Year 11, No. 44, Art.5(4)

${ }^{73}$ See above notes 67 ; the writer W/gebriel has tried to show the problems in the valuation system and the amount of compensation awarded for affected people 
Besides, there are also variations between the federal rural land law and some regional states counterpart in defining and manner of determining the 'public purpose'. The prominent instance in this regard is the rural land laws of the Oromia and Southern Nations, Nationalities and Peoples States. These laws have defined the public purpose narrowly compared to the federal rural land law so that they protect the individuals' property right and provide tenure security of individuals land right in better way. In fact, the Oromia state rural land law has not clearly defined the public purpose. Yet, it has some remarks that indicate the extent to which the interpretation of the concept goes. Accordingly, in this law term 'public use' stretches to expropriate rural land for urban growth provided that the community has consented thereof. ${ }^{74}$ But, the law doesn't considered acquiring land to lease to private development (investment) as a public use. This is inferred when the legislation prohibits the government from renting rural land held by peasants or pastoralists. ${ }^{75}$

In fact, the Oromia state rural land law has not clearly defined the public purpose. Yet, it has some remarks that indicate the extent to which the interpretation of the concept goes. Accordingly, in this law term 'public use' stretches to expropriate rural land for urban growth provided that the community has consented thereof. ${ }^{76}$ But, the law doesn't considered acquiring land to lease to private development (investment) as a public use. This is inferred when the legislation prohibits the government from renting rural land held by peasants or pastoralists. ${ }^{77}$

On the other side, the SNNP state rural land law defined the concept in a way to imply the expropriation of rural land to be conducted for the projects for which the public derives direct or actual benefit. Under this law 'public use' is defined as:

"Public common service obtained from infrastructures such as school, health, road, water, etc." 78

According to this definition public use is interpreted in open-ended manner only referring to the direct benefits the society would probably derive from the purpose to which peasants' and pastoralists' rural landholdings are compulsorily acquired. It has limited the discretion of public authorities in determining the purpose to which peasants' rural landholdings compulsorily acquired. Thus, the government can expropriate peasants' rural landholding for the purposes from which the society is able to derive a direct benefit. Since, the listing in the definition is not exhaustive the government can includes other purposes as well provided that they are the same in nature with the listed ones. Consequently, it avoided the possibility of expropriation of land to transfer to private investors. Nonetheless, the regulation promulgated to implement this proclamation of the region has opened a loophole to the government to include 'indirect benefits of the society' standard in specifying the public purpose. This is extrapolated while the regulation obliges rural landholders to surrender their holdings in case when a project

\footnotetext{
${ }^{74}$ Oromia National Regional State, Proclamation to amend the Proclamation No. 56/2002, 70/2003, 103/2005 of Oromia Rural Land Use and Administration, Proclamation 130/2007, Megelata Oromia 15 ${ }^{\text {th }}$ Year, No.12, (hereinafter cited as Oromia rural land Proc.No.130/2007), Art.13(2)

${ }^{75}$ Oromia Rural land Proc. No. 130/2007, Art.11(1)

${ }^{76}$ Oromia Rural land Proc. No. 130/2007, Art.13(2)

${ }^{77}$ Oromia Rural land Proc. No. 130/2007, Art.11(1)

78 Southern Nations, Nationalities and Peoples Regional State, The Southern Nations, Nationalities and Peoples Regional State Rural Land Administration and Utilization Proclamation, Proclamation 110/2007, Debub Negarit Gazeta $13^{\text {th }}$ Year No.10, (hereinafter cited as SNNPR Rural land Proc. No. 110/2007), Art.2(23)
} 
(government or private investor owned) believed to contribute for the development of the region and the growth of the area has been prepared. ${ }^{79}$

However, the difference between the federal rural land law and the Oromia region's counterpart regarding the stipulation they have made on the purpose for which the government can expropriate peasants' rural land rights exposes peasants in the region for double-standards of treatment. Particularly, this situation happens due to the federal law consideration of the land acquiring of government for provision of private investors as 'public purpose' while the Oromia region's not. Indeed, legally speaking this difference may not be considered apparent conflict to warrant rule of interpretation of law to identify the prevailing one. Because, they regulate and apply in different situations; i.e. the federal law provision applies for rural land expropriation decisions to be made by the federal government based on its powers and functions enshrined in the FDRE constitution; whereas, the region's equivalent put into operation for regional government's expropriation decision in accordance to its constitutional powers and functions. Nonetheless, these dissenting rules again govern the same subjects - peasants with rural land rights in Oromia region.

Moreover, though this exclusion under Oromia region's land law narrows the possibilities of peasants' eviction compared to the federal legislation, the question of legality rises here. To answer it we have to look into the FDRE Constitution on division of powers between the federal and State governments. The FDRE Constitution after adopting the federal system it has apportioned power and functions among the two levels of government. According to the Constitution the federal government has the exclusive authority on those powers and functions that have listed under article $51 ;^{80}$ and the federating States are remained with the residual powers and functions that are not exclusively given to the federal government and concurrently to the federal and State governments. ${ }^{81}$

One of such division of powers revolves around the issue of land. The FDRE Constitution under article 51(5) has authorized the federal government to enact laws relating to utilization and conservation of land while allotting the task of administering land (referring to performance of executive duties of the government) in accordance with the federal laws to the federating polis under article $52(2(\mathrm{~d})) .{ }^{82}$ Both entities are given different aspects of the same subject matter. (assefa)Then, from these provisions we can infer that enacting rural land utilization and conservation laws is inherent power of the federal government and administering rural land utilization and conservation in accordance with the federal laws thereof is the prerogative of regions. However, the constitution is not clear enough in specifying the content of the federal rural land laws since it has not defined the phrase 'land utilization and conservation'.

Nevertheless, for the writer the Constitution seems to entitle the federal government to enact rural land laws that define the rural land tenure system by which the nature and content of property rights in land; the conditions under which these rights are to be held and enjoyed; and the restrictions imposed thereof are determined. ${ }^{83}$ This is because in order to establish a single economic community in the country which is one of the objectives of the

${ }^{79}$ Southern Nations, Nationalities and Peoples Regional State, The Southern Nations, Nationalities and Peoples Regional State Rural Land Administration and Utilization regulation, Council of Regional Government regulation No.66/2007, Debub Negarit Gazeta $7^{\text {th }}$ year No.66, Art.13(3(a))

${ }^{80}$ FDRE Constitution, Art.51

${ }^{81}$ FDRE Constitution, Art.52

${ }^{82}$ FDRE Constitution, Art.51(5) and Art.52(2(d))

83 White, C.M.N. 1959, A Survey of African Land Tenure in Northern Rhodesia, in Journal of African Administration, Vol. 11 No. 4, October, pp. 171-178, p.172 
constitution, the statutory land tenure system that regulates Ethiopian peasants and pastoralists rural land rights must be uniform all over the country.

Hence, the writer believes that the constitution has empowered the federal government to enact rural land laws that defines the rural land tenure system wherein the nature and content of property rights in land of the landholder; the conditions under which these rights are to be held and enjoyed by the landholder; and the restrictions imposed on such rights of landholder are delineated. In other words, it is constitutionally granted power of the federal government to define rights of peasants, how such rights are acquired, what they consist of, how they operate in the holding, transfer and inheritance of land and how they may be extinguished - one of the ground is 'public purpose'.

Furthermore, the federal rural land law has not given all detail rules of rural land tenure. It has left by way of delegation some rules of land tenure to be determined by the States' laws. ${ }^{84}$ This is in fact has done in accordance with the FDRE Constitution's stipulation that authorizes the federal government to delegate its constitutionally granted powers to States when it is necessary. ${ }^{85}$ While delegating the power of enacting rural land use laws to each States, the federal government has claimed the States' laws to be in conformity with the framework law it has enacted and to be detail enough to implement the same. ${ }^{86}$

However, since, defining the grounds to extinguish peasants' land rights is one aspect of land tenure; it is the federal government that determines the grounds thereto. One of the grounds is the compulsory acquisition of land rights for "public purpose". Therefore, it is the federal government that has the power to determine the constituting elements of 'public purpose'. As per the discussion made above the federal government has already determined the component of public purpose that includes transfer of land to an investor. To that effect, while excluding the acquiring of land for investors from the scope of "public purpose" for expropriation of peasants' and pastoralists' land rights, the Oromia region's land law is seems to regulate beyond the delegation.

In relation to the public participation in scrutinizing the satisfaction of 'public purpose' requirement the federal rural land laws have not made it as a condition. It is rather some states' rural land laws that have clearly required consultation of the public. This is, in fact, in line with the constitutional rights of citizens to be consulted with respect to policies and projects affecting their community. ${ }^{87}$ Moreover it somehow limits the discretionary power of the public authorities in determining the purposes to which land is expropriated and thereby attain the intended balance. Nevertheless, these laws are not similar in regulating it. The Oromia and SNNP states' rural land laws seem to restrain the power of the state to expropriate holdings of peasants or pastoralists for public purpose thorough participation of the local community. ${ }^{8889}$ Whereas, some States' laws limit the public hearing for expropriation of peasants or pastoralists land holdings in certain situations. For instance, the Amhara state's legislation demands public hearing of the Kebele residents where it is found that the purpose of expropriating the land is directly interrelated with development of local community or where the community itself is being a payer of compensation

\footnotetext{
${ }^{84}$ FDRE rural land Proc. No. 456/2005, Art.17(1)

${ }^{85}$ FDRE Constitution, Art.50(9)

${ }^{86}$ FDRE rural land Proc. No. 456/2005, Art.17(1)

${ }^{87}$ FDRE Constitution, Art.43(2)

${ }^{88}$ Oromia Rural land Proc. No. 130/2007, Art.13(2)

${ }^{89}$ SNNPR Rural land Proc. No. 110/2007, Art.13(11)
} 
thereof. $^{90}$ To be more effective, however, it is better to extend it to the situation where the purpose of expropriating the land assumed to benefit the society indirectly; like expropriation to lease to private investors. It is because, mostly, public scrutiny is needed to ensure the balance between public need for land and the provision of land tenure security, in the event where the expropriation conducted for the indirect benefit of the society. ${ }^{91}$

Finally, the discussion made in section three has revealed that the conflicting interests involved in expropriation proceedings are balance when the legislation guaranteed the affected peoples with right to appeal to an independent body. Thus, that is why the FAO has claimed legislations to guarantee the procedural rights of affected peasants, including the right to be heard, and the right to appeal to an independent body during compulsory acquisition so that a balance is maintained between the public need for the land and protection of property rights and provision of land tenure security of the affected peoples. ${ }^{92}$

Under rural land laws of Ethiopia, however, the affected peoples are not allowed to challenge or appeal to court of law or an independent body against the purpose for which one's rural landholding is compulsory acquired. ${ }^{93}$ The woreda administration or higher federal or regional government organ is not subjected to check and balance through courts of law with regard to its power of determination of public purpose. This is implied from the laws which have expressly entitled the affected peoples to take their grievance on the level of compensation. ${ }^{94}$ Thus, the $a$ contrario sensu of this stipulation reveals that unless the affected peoples are aggrieved with the amount of compensation awarded, they have no opportunity to access justice for independent organ on other grounds; like objecting the project for which the expropriation conducted does not satisfy the public purpose requirement.

Moreover, challenging the decisions of expropriation in this ground would be highly difficult for affected peoples in Ethiopia if it were allowed. Because, the purposes for which compulsory acquisition of land is authorized have been not listed either in exhaustive or open-ended manner in the legislation.

Nonetheless, under Amhara region's rural land legislation it appears that the affected peoples are authorized to challenge the expropriation decision on the ground that the purpose for which their land has been expropriated does not satisfy the public purpose requirement within the administrative body. This is indicated while the region's law states ${ }^{95}$

"Where a land holder or user who may concern the matter has legal ground of his rejecting the request of land expropriation, he may submit his [compliant] to the Authority government office next to the body who has given the decision within 15 days from the date of his communication of the notice in writing. The decision may be given by the Authority government office shall be final."

However, the problem with the Amhara region's rural land law is that in nowhere it considered challenge against the purpose for which compulsory acquisition of land has made as a legal ground to claim administrative review of the

90 Amhara National Regional State, Rural Land Administration and Use System Implementation, Council of Regional Government Regulation No.51/2007, Zihikre-hig, year 12 No.14, (hereinafter cited as Amhara Rural land Reg. No.51/2007), Art.29(2)

91 Above notes 2, p.12

92 Above notes 2, p.5 and 55

${ }^{93}$ It is again difficult to assume that courts are independent and competent to handle the public purpose issue if allowed them to do so in Ethiopia

${ }^{94}$ FDRE Land Expropriation Proc. No.455/2005, Art.11(1) and (4); Amhara Rural land Reg. No.51/2007, Art.33(1) and (5); and Benishangul Gummuz region's draft rural land administration and use regulation drafted in 2010, Art.31(1) and (5)

${ }^{95}$ Amhara Rural land Reg. No.51/2007, Art.29(5) 
expropriation decision. Moreover, the reviewing administrative body is not independent as it is the authority government office next to the expropriating body. Hence, in the opinion of the writer, the existence of administrative review of expropriation decision on the ground of non- fulfilment of public purpose requirement is questionable.

\section{Conclusion}

Therefore, from the above analysis of rural land laws of Ethiopia, the essence of 'public purpose' in expropriation of rural landholdings is interpreted broadly and vaguely leaving it to be determined by the public authority. No one can be sure or aware of what constitutes public purpose; and able to predict what the possible public purposes are particularly in relation to peasants' and pastoralists' landholding. Concerning investors, they are at least sure that their rural landholding will not be expropriated unless it is needed for development projects carried by the government only. This differential treatment has not been supported by economic justification. Rather, it contradicts with the priority right guaranteed to peasants and pastoralists in access to rural land.

Moreover, this situation affects the property rights and undermines the land tenure security of the peasants and pastoralists by allowing the State an extensive use of the power of expropiration; and creating loophole for abuse of power; and incentives for corruption by private investors who try to influence processes to their own advantage. Although there is a doubt in legality, this problem is somehow mitigated in Oromia State since its rural land law prohibited expropriation of peasants' and pastoralists' landholding to transfer to investors. However, the problem is more aggravated through the country because of the legislation failure to allow the involvement of independent well-established processes in the determination of the 'public purpose' by the means of appeal. 